ISSN : 2549-0532 (Cetak)

\title{
TINGKAT PENGETAHUAN KADER TENTANG POSYANDU DI PUSKESMAS TEMINDUNG KOTA SAMARINDA
}

\author{
Fransiska Keron Ola \\ STIKES Dirgahayu Samarinda \\ Email:cerollao@gmail.com
}

\begin{abstract}
Dikirim : 9 Juli 2020
Diterima :8 Agustus 2020

Diterbitkan : 10 September 2020
\end{abstract}

\begin{abstract}
Community health workers are selected by the community from community members who are willing to voluntarily be able to help and have time to organize basic health service activities. The purpose of this study was to determine the level of knowledge community health workers in basic health service the health centers in Temindung, Samarinda. The research subjects of community health workers were 32 people who were on duty in basic health service activities in 10 basic health service centers in Temindung Samarinda. Measuring the level of knowledge of community health workers using a questionnaire. Percentage analysis to determine the level of knowledge about basic health service. Most community health workers are chosen directly with the essential requirements of being able to read, write and be friendly and voluntarily help and be in their community. Although their knowledge of basic health services is still low with $87.5 \%$ of basic health service. Knowledge of community health workers is still low Even though their knowledge is lacking, they still do health services at basic health services once a month. Basic health services are an important part of health services in the community, especially helping health workers in public health services to the community, but so they are expected to get training in basic health services to improve the Indonesian health republic's work program.
\end{abstract}

Keywords: Knowledge, Basic health service (Posyandu), Community Health Worker's(Kader 
Jurnal Kebidanan Mutiara Mahakam, Vol 8 , No 2, Tahun 2020, Hal 120-126

\section{PENDAHULUAN}

Posyandu adalah bentuk upaya kesehatan berbasis masyarakat yang dikelola dari, oleh, untuk dan dengan masyarakat, untuk memberdayakan masyarakat dan memberikan fasilitas kepada masyarakat dalam memperoleh layanan kesehatan dasar.

Upaya meningkatkan peran dan fungsi Posyandu bukan semata-mata tanggung jawab pemerintah, tetapi semua komponen dalam masyarakat, termasuk kader (Kader). Peran kader dalam pelaksanaan Posyandu sangat besar karena selain memberikan informasi kesehatan kepada masyarakat serta penggerak masyarakat untuk datang ke Posyandu dan melakukan perilaku hidup bersih dan sehat (RI, 2012).

\section{METODE PENELITIAN}

\section{Desain penelitian}

Jenis penelitian ini menggunakan jenis penelitian kuantitatif dengan menggunakan variabel independen untuk menganalisis tingkat pengetahuan Kader / (Kader) tentang Posyandu dengan kriteria Inklusi Kader Posyandu dapat membaca dan menulis, berjiwa social dan mau bekerja secara relawan, Mengetahui adat istiadat serta kebiasaan masyarakat, mempunyai waktu yang cukup, bertempat tinggal di wilayah posyandu, berpenampilan ramah dan simpatik, mengikuti pelatihan-pelatihan sebelum menjadi kader posyandu. Kriteria eksklusi berusia lanjut atau lansia.

\section{Subjek penelitian}

Subjek penelitian adalah ibu-ibu kader yang bertugas di Posyandu khususnya di wilayah kerja Puskesmas Temindung Samarinda.

\section{Tempat dan waktu}

Data dikumpulkan pada bulan Maret sampai Mei Tempat penelitian di Posyandu (Mentimun, Anyelir, Rambutan, Lubuk Sawah, Melati, Hibrida, Delima, Fajar Harapan, Andika) di Puskesmas Temindung Samarinda dari bulan Mei-Juli 2019.

\section{Instrumen Penelitian}

Pengukuran pengetahuan kader / kader Posyandu menggunakan kuesioner tingkat pengetahuan kader.

\section{Analisis data}

Untuk menjawab masalah penelitian, data yang dikumpulkan dengan dipelajari secara komprehensif dan hasil dianalisis menggunakan excel: semua data yang telah dikumpulkan 
Jurnal Kebidanan Mutiara Mahakam, Vol 8 , No 2, Tahun 2020, Hal 120-126

dari sumber penelitian dibahas oleh penulis menggunakan analisis deskriptif dengan menggunakan perhitungan persentase atau yang biasa disebut dengan frekuensi relatif.

\section{HASIL DAN PEMBAHASAN}

1. Analisis demografi responden

Penelitian ini dilakukan di Posyandu Puskesmas Temindung Samarinda, khususnya pada kader posyandu Puskesmas Temindung Samarinda.

a. Distribusi karakteristik responden berdasarkan usia kader Posyandu Puskesmas Temindung Samarinda

Tabel 1 distribusi karakteristik responden berdasarkan usia.

\begin{tabular}{lll}
\hline \multicolumn{1}{c}{ Usia } & \multicolumn{1}{c}{$\mathrm{F}$} & \multicolumn{1}{c}{$\%$} \\
\hline 26-35 Tahun & 4 & 12.5 \\
36-45 Tahun & 11 & 34.37 \\
46-55 Tahun & 12 & 37.5 \\
56-65 Tahun & 3 & 9.38 \\
66 Tahun & 2 & 6.25 \\
\hline Total & 32 & 100 \\
\hline
\end{tabular}

Berdasarkan distribusi karakteristik responden berdasarkan usia dengan responden umur 26-35 Tahun sebanyak 12.5\%, responden 36-45 tahun sebanyak 34.37\%, usia 46-55 tahun sebanyak 37.5\% merupakan responden masa lansia awal, usia 56-65 tahun responden lansia akhir sebanyak $9.38 \%$ dan responden tertua dengan usia 66 tahun sebanyak $6.25 \%$ merupakan usia manula.

Responden terbanyak 46-55 tahun dengan 37.5\% merupakan responden lansia awal.

b. Distribusi karakteristik responden berdasarkan jenis kelamin kader Posyandu di Puskesmas Temindung Samarinda

Tabel 2 Distribusi Responden berdasarkan jenis kelamin

\begin{tabular}{lll}
\hline Jenis kelamin & F & $\%$ \\
\hline Perempuan & 32 & 100 \\
Laki-laki & - & - \\
\hline Total & 32 & 100
\end{tabular}

Berdasarkan distribusi karakteristik responden berdasarkan jenis kelamin kader Posyandu di Puskesmas Temindung Samarinda seluruh kader berjenis kelamin perempuan dengan $100 \%$. Seluruh anggota kader berjenis kelamin perempuan karena untuk menjadi 
Jurnal Kebidanan Mutiara Mahakam, Vol 8 , No 2, Tahun 2020, Hal 120-126

kader posyandu di butuhkan kesabaran dan ketelatenan dalam melakukan pekerjaan Posyandu setiap bulan.

c. Distribusi karakteristik responden berdasarkan Status perkawinan Kader Posyandu di Puskesmas Temindung Samarinda.

Tabel 3 Distribusi responden berdasarkan status perkawinan

\begin{tabular}{lcc}
\hline Status Perkawinan & F & $\%$ \\
\hline Menikah & 32 & 100 \\
Tidak menikah & - & - \\
\hline Total & 32 & 100 \\
\hline
\end{tabular}

Berdasarkan distribusi karakteristik responden berdasarkan Status perkawinan Kader Posyandu di Puskesmas Temindung Samarinda 100\% menikah. Seluruh responden mempunyai status perkawinan dengan status menikah.

d. Distribusi karakteristik responden berdasarkan tingkat pendidikan Kader Posyandu di Puskesmas Temindung Samarinda.

Tabel 4 Distribusi responden berdasarkan tingkat pendidikan

\begin{tabular}{lcc}
\hline Tingkat & F & $\%$ \\
Pendidikan & & \\
\hline SD & 7 & 21.87 \\
SMP & 9 & 28.13 \\
SMA & 14 & 43.75 \\
Sarjana & 2 & 6.25 \\
\hline Total & 32 & 100 \\
\hline
\end{tabular}

Berdasarkan distribusi karakteristik responden berdasarkan tingkat pendidikan Kader Posyandu di Puskesmas Temindung Samarinda 21.87\% responden berpendidikan SD, 9\% responden mempunyai pendidikan SMP, $43.75 \%$ responden berpendidikan SMA, $6.25 \%$ responden berpendidikan Sarjana. responden berpendidikan SMA sebesar $43.75 \%$ artinya responden menempuh pendidikan sekolah menengh atas sesuai dengan pendidikan responden tersebut maka Kader kesehatan di posyandu menggerti bagaimana cara menggurus kegiatan Posyandu karena sudah mempelajari berbagai macam ilmu dan pengetahuan yang sangat luas. 
Jurnal Kebidanan Mutiara Mahakam, Vol 8 , No 2, Tahun 2020, Hal 120-126

e. Distribusi karakteristik responden berdasarkan tingkat pekerjaan Kader Posyandu di Puskesmas Temindung Samarinda

Tabel 5 Distribusi responden berdasarkan Tingkat pekerjaan

\begin{tabular}{lcc}
\hline Pekerjaan & F & $\%$ \\
\hline Wiraswasta & 8 & 25 \\
IRT & 24 & 75 \\
\hline Total & 32 & 100 \\
\hline
\end{tabular}

Berdasarkan distribusi karakteristik responden berdasarkan tingkat pekerjaan Kader Posyandu di Puskesmas Temindung Samarinda 75\% responden dengan status ibu rumah tangga, dan $25 \%$ responden bekerja. $75 \%$ responden tidak bekerja, akan tetapi berstatus ibu rumah tangga serta $25 \%$ responden dengan status bekerja sebagai wiraswasta.

2. Data khusus

Pengetahuan Kader Tentang Posyandu

Tabel 6 Distribusi pengetahuan kader Posyandu di Puskesmas Temindung tentang posyandu

\begin{tabular}{lcc}
\hline Pengetahuan & F & $\%$ \\
\hline Baik & 4 & 12.5 \\
Kurang & 28 & 87.5 \\
\hline Total & 32 & 100 \\
\hline
\end{tabular}

Berdasarkan distribusi pengetahuan kader Posyandu di Puskesmas Temindung tentang posyandu sebesar $87.5 \%$ kurang dan $12.5 \%$ pengetahuan responden Kader dengan pengetahuan baik. Berdasarkan prosentase pengetahuan responden kurang yaitu $87.5 \%$ karena responden hanya mempunyai pendidikan terakhir SD serta persyaratan menjadi responden hanya di butuhkan kader yang ramah, mempunyai jiwa social yang tinggi, dapat menulis dan membaca serta berasal dari masyarakat setempat untuk menjadi responden.

Konstitusi Indonesia 8 tahun 2019 tentang pemberdayaan orang kesehatan dalam kader 7 ayat 2 berperan sebagai: a) Pelaku masyarakat untuk berpartisipasi dalam upaya kesehatan sesuai dengan kewenangannya, b) pelaku masyarakat untuk memanfaatkan UKMB (Usaha Kesehatan Bersumber daya Masyarakat) dan dasar layanan kesehatan, C) Manajer UKBM, d) Pendidik kesehatan kepada masyarakat, e) rekaman kegiatan 
Jurnal Kebidanan Mutiara Mahakam, Vol 8 , No 2, Tahun 2020, Hal 120-126

pemberdayaan masyarakat di sektor kesehatan, f) reporter jika ada masalah atau kasus kesehatan lokal pada petugas kesehatan (RI, 2012).

Petugas kesehatan masyarakat - yang berasal dari komunitas yang mereka layani, bertanggung jawab kepada komunitas-komunitas ini, dan menerima pelatihan yang lebih pendek dari yang dibutuhkan untuk dokter, perawat, atau profesional kesehatan lainnya mewakili "mata rantai" yang esensial antara kerinduan masyarakat yang luas dengan masyarakat. yang sama-sama membutuhkan bantuan dan berfungsi sebagai kendaraan penting untuk kemajuan. Hanya sedikit, jika ada, alat kesehatan dan pengembangan kami yang cocok dengan potensi petugas kesehatan masyarakat untuk mendorong keuntungan di berbagai bidang. Sejumlah besar bukti menunjukkan bahwa petugas kesehatan masyarakat meningkatkan penggunaan layanan kesehatan, mengurangi kesenjangan kesehatan, menyediakan layanan berkualitas tinggi dan meningkatkan hasil kesehatan secara keseluruhan. Program pekerja kesehatan masyarakat juga mewakili pekerjaan yang baik, mendukung ekonomi nasional dan lokal dan meningkatkan produktivitas dengan meningkatkan kesehatan dan kesejahteraan. Investasi pada pekerja kesehatan masyarakat juga akan memungkinkan Afrika untuk mengubah proyeksi populasi anak muda yang hampir dua kali lipat hingga 2050 dari "kaum muda" yang berpotensi berbahaya menjadi "demografis yang terbagi" yang dinamis yang mendorong pertumbuhan ekonomi dan meningkatkan standar kehidupan. Memang, investasi pada petugas kesehatan komunitas merupakan peluang ideal untuk mengatasi salah satu masalah paling menjengkelkan di Afrika - yang sangat tinggi tingkat pengangguran di kalangan kaum muda (Afrika, 2017).

\section{SIMPULAN}

Berdasarkan hasil analisis dan diskusi yang diuraikan, kesimpulan tingkat pengetahuan kader tentang Posyandu dengan presentase sebesar 87,5\% Kurang. Berdasarkan penjelasan di atas, dapat ditarik benang merah bahwa Hambatan terhadap Peran Kader Posyandu dalam Pembangunan Kesehatan Masyarakat terletak pada pengetahuan kader Posyandu yang masih membutuhkan perhatian. Diharapkan akan ada pelatihan untuk kader Posyandu sehingga peran kader terlaksana dengn baik.Adapun peran kader posyandu adalah Peran Kader Posyandu Terhadap Pembangunan Kesehatan Masyarakat menyimpulkan 1. Peran kader dalam Kegiatan Kader Posyandu terhadap 
Jurnal Kebidanan Mutiara Mahakam, Vol 8 , No 2, Tahun 2020, Hal 120-126

pengembangan kesehatan meliputi kegiatan layanan KIA (Kesehatan Ibu dan Anak), Layanan Keluarga Berencana, Layanan Imunisasi, Layanan Gizi, dan layanan Manajemen Diare dan penyakit menular lainnya. 2. Peran kader Posyandu dalam pembangunan kesehatan cukup tinggi, ini bisa dilihat dari tingkat kegiatan dan tujuan program. 3. Hambatan yang dialami kader dalam melakukan kegiatan pembangunan adalah mayoritas kader di tingkat pendidikan masih kurang dan belum mendapatkan pelatihan tentang tugas sebagai kader posyandu secara maksimal.

\section{DAFTAR PUSTAKA}

Africa, S. (2017). SOFI 2017 : Questions \& Answers.

Advocacy, C. (2008). Community Health Workers ( CHWs ).

Factors impacting the effectiveness of community health worker behavior change a literature review. (2015).

Karol, Ghan Shyam (2015) Community Health Workers and Reproductive and Child Health Care : An Evaluative Study on Knowledge and Motivation of ASHA ( Accredited Social Health Activist ) Workers in Rajasthan , India. Volume: 4, Pages: 137-150, Issue: 9

Liu, Anne, Sullivan et al (2011). Community health workers; contin-; global health; health systems; human; lages project; management; millennium vil-; primary healthcare; resources for health; scalability; scale-up; uum of care. Pages 419-435. DOI: 10.1002/MSJ

Rosenthal, By E Lee, Brownstein et al (2010). Community Health Workers: Part Of The Solution.

Ri, K. K. (n.d.). Ind p.

Ri, K. K. (2012). Ayo ke POSYANDU.

Swechhya, Baskota, Kamaraj, R (2014). Female Community Health Volunteers Program in Nepal : Perceptions, Attitudes and Experiences on Volunteerism among Female Community Health Volunteers. Volume: 1, Pages: 9-15, Issue: 5

Tse, A. D. P., Suprojo, A., \& Adiwidjaja, I. (2017). Kesehatan Masyarakat, 6(1), 60-62. 